\title{
Конфессиональная лексика в русском переводе энциклики папы Франциска Laudato si'- пространство традиции и современности
}

\section{Religious lexis in the Russian translation of the encyclical letter Laudato si' of Pope Francis - the space of tradition and contemporary times}

\begin{abstract}
The paper provides a study of religious lexis excerpted from the Russian translation of the encyclical letter Laudato si'. The Russian version of the encyclical was translated and published by Russian Franciscan Publishing House. The analyzed material consisting of single words, as well as compound multi-word expressions, related to the Catholic denomination (264 lexical items 1000 uses, which accounts for $14 \%$ of the entire encyclical), was grouped into semantic fields. The vocabulary was described in terms of the semantics and its functioning and codification, both in the contemporary Russian religious language and in general Russian language. It was assumed that the encyclical is addressed not only to the representatives of the Church hierarchy but also to all the faithful. Hence, there was the need to draw attention to the pragmatic aspects of the religious language, including the balance between comprehensibility and the use of specialist theological terminology in the translated text. It was demonstrated that the majority of the lexical items of religious terminology is coded by the explanatory dictionary of the contemporary Russian language, except for 14 lexical items related to the Catholic denomination that enhance the lexis of the contemporary Russian language.
\end{abstract}

Keywords: religious lexis, semantic field, theolinguistics, Russian translation, papal documents

Małgorzata Wideł-Ignaszczak, Katolicki Uniwersytet Lubelski Jana Pawła II, Lublin - Polska, mwidel@kul.pl, ORCID ID: https://orcid.org/0000-0001-9250-1774

\section{Конфессиональная лексика как составляющая религиозного дискурса}

В современной теолингвистике существует ряд понятий, определяющих лексику, связанную с сакральной сферой. Понятие религиозная лексика трактуется неоднозначно, поскольку не решена проблема его соотношения с по- 
нятиями цеерковная лексика, библейская лексика, конфессиональная лексика. Вопрос о соотнесении понятия религиозная лексика с другими схожими понятиями можно решить, исходя из семантической наполненности самих терминов (Âkimov 2011: 75; Âkimov 2013: 66-69).

В настоящей статье мы предлагаем логическое обоснование выбора термина конфессиональная лексика, поскольку анализируемый нами источник относится к римско-католическому вероисповеданию. Оно не полностью синонимично понятию религиозная лексика. В нашем понимании конфессиональная лексика является частью религиозной лексики как более широкого семантического объединения и ограничивается рамками данного понятийного религиозного пространства. Поэтому мы сознательно не анализируем религиозную лексику, денотативно относящуюся к другим конфессиям и одновременно не выступающую в католическом понятийном пространстве. Следовательно, католическая религиозная лексика является лишь частью всей религиозной лексики.

Это своего рода продолжение классификации Кирилла Алексеевича Тимофеева, согласно которой выделяются три группы религиозной лексики: общерелигиозная лексика (слова, обозначающие понятия, свойственные всем монотеистическим религиям: Бог, душа, молитва и т. д.); общехристианская лексика (слова, обозначающие понятия, свойственные всем христианским конфессиям: Святая Троица, Святой Дух, Спаситель, апостол, Евангелие, Церковь, исповедь и т. д.); частнохристианская лексика (слова, обозначающие понятия, свойственные отдельным христианским конфессиям: батюшка, пастор, ксендз, кюре, аббат, кардинал, обедня, утреня, всенощная, месса, лития, литания и т. д.) (Timofeev 5).

В свою очередь, Ольга Александровна Прохватилова выделяет три тематические группы сакрально-богослужебной лексики, которые чаще всего встречаются в православных проповедях: лексемы, обозначающие названия церковных праздников; лексические единства, отражающие постулаты христианского вероучения, нравственно-религиозной этики; наименования важнейших понятий Христианства и Православия (Prohvatilova 224-225; ср. Gadomskij 2007: 287-296).

Учитывая жанр энциклики, мы построили другую классификацию, так как религиозный язык обладает собственной спецификой, исходя из особого характера сферы применения (Makuchowska 55; cp. Nagórko 188). Лексический уровень является одним из важнейших компонентов языковой организации современного церковного текста, который принимает участие в формировании его коммуникативной направленности.

При изучении материала для настоящей статьи использовались методы сплошной выборки, лингвистического наблюдения и описания, позволив- 
шие рассмотреть функционирование языковых единиц в анализируемом тексте, а также метод количественного подсчета языковых единиц. С точки зрения лексической семантики стилевые особенности современного религиозного текста проявляются прежде всего в наличии единиц тематической группы католическое конфессиональное пространство.

В связи с вышесказанным мы формулируем тезис о том, что религиозная лексика, с одной стороны, отражает многовековую традицию христианства, с другой стороны, функционирует в современном мире, отвечает коммуникативным потребностям современных верующих людей и таким образом отражает конфессиональное понятийное пространство традиции и современности.

\section{Жанр энциклики как пространство sacrum и profanum}

Источником наших исследований является один из жанров религиозного языка, связанный с пастырской деятельностью Церкви, - энциклика. Воспринимая официальный текст документа, с одной стороны, замечаем трудный герметичный язык теологии и официального стиля, но с другой данный текст можно рассматривать как универсальное послание, затрагивающее практически все сферы человеческого существования (ср. Gajda 273274). Это жанр, которому уделяется немного внимания в русской и польской теолингвистике. Александр Казимирович Гадомский, сосредоточиваясь на жанровом (генологическом) подходе к изучению религиозного языка, констатирует, что „религиозный язык можно понимать и как систему жанров, многие из которых совпадают с жанрами светского языка" (Gadomskij 2009: 108). Одновременно языковеды подчеркивают, что имеются в религиозном языке свои специфические жанры (ср. Ма 320; Ârmul'skaâ 147-150). При этом в языке отдельных религий могут быть жанры, свойственные только языку конкретной религии. Таким жанром является энциклика. В Русской православной церкви ей соответствует жанр окружного послания.

Энциклика в католической литературе - это письменное обращение римского понтифика к определенной группе людей и/или ко всему человечеству, разъясняющее определенные религиозные вопросы (Ceglińska 152). Энциклики церковных иерархов являются основополагающими документами, имеющими силу закона. Они посвящаются вопросам веры, морали, сакральной сфере верующих, но также затрагивают современные социально-политические вопросы (Mitrohin 540).

Папские высказывания отражают специфические условия и цели документа как своим содержанием (тематикой) и языковым стилем, то есть от- 
бором словарных, фразеологических и грамматических средств языка, так и композиционным построением.

По мнению Гадомского, все эти три момента - тематическое содержание, стиль и композиционное построение - неразрывно связаны в целом высказывании и одинаково определяются спецификой данной сферы общения (Gadomskij 2009: 108). В настоящей статье особое внимание мы сосредоточим лишь на лексике.

Энциклика Папы Франциска - это документ, целью которого является формировать у всех читающих глубокое экологическое сознание (Klimek 25). Артур Высоцки констатирует, что „еncyklika Laudato si’ papieża Franciszka niejako reasumuje nauczanie społeczne Kościoła odnośnie do ekologii [...]" (Wysocki 213). Это вторая энциклика папы Франциска от 2015 года. Русский перевод энциклики выполнен Издательством Францисканцев в том же году. Анализируемая энциклика - это религиозный документ Римско-католической церкви, затрагивающий актуальные вопросы, связанные с заботой о защите окружающей среды и благосостоянии всего творения. В ней рассматриваются современные доктринальные и организационные общецерковные вопросы.

Существенной чертой этого текста являются многочисленные ссылки на документы предшественников папы Франциска, например, Бенедикта XVI и Иоанна Павла II и др. Список учений пап в энциклике Laudato si' определяет векторы и доминанты, затрагиваемые папой Франциском. Ян Климек подчеркивает также заботу автора энциклики о новом языке и о стиле богословского дискурса (Klimek 28-30). Богословы акцентируют внимание на том, что в сравнении с документами предыдущих пап язык этой энциклики более современный, простой, глубоко проницательный и междисциплинарный. Он не является типично богословским, и вследствие этого его не характеризует обилие богословской терминологии и отвлеченность:

W porównaniu z dokumentami poprzednich papieży, zastanawia język ekologicznej encykliki papieża Franciszka. Jest on prosty, głęboko refleksyjny, zwięzły i wyraźnie interdyscyplinarny. Język papieskiej enuncjacji nie stroni od emocji oraz posługuje się często obrazem i opisem [...] nie jest przy tym językiem typowo teologicznym [tzn. nie cechują go - dop. M.W.-I. doktrynalizm i spekulatywność] (Klimek 30).

\section{Критерии выбора материала}

Приведенные выше характеристики повлияли на наш интерес к детальному анализу богословской составляющей в современном религиозном дискурсе на примере энциклики Laudato si’. На основе анализа мы пришли 
к выводу, что в силу тематики - экологического кризиса в мире и отношения к нему Католической церкви - религиозная лексика составляет в документе небольшой процент от всего словарного фонда, насчитывающего 71422 слова, - 14\%. Мы отобрали методом сплошной выборки 264 единицы в 1000 употреблениях. Своеобразно устанавливаются также семантические группы. Лексика не является случайным изолированным набором слов, а представляет собой связанную лингвистическую подсистему, которая создает различные синонимические, антонимические, подчинительные и другие системы. Семантические поля содержат одни и те же общие семантические компоненты. Это слова и коллокации, значения которых состоят из одинаковых компонентов, расположенных в различных комбинациях, или те, в которых основное ядро семантических компонентов является общим, а различия состоят из отдельных элементов (Grzegorczykowa 101, cp. Tokarski 1984, 1993). Мы выделили 11 семантических полей:

1) номинации Трансцендентного Существа (теонимы): 72 единицы в 329 употреблениях;

2) номинации святых, блаженных и библейских персонажей: 19 единиц в 43 употреблениях;

3) номинации священнослужителей и представителей церковной иерархии: 15 единиц в 72 употреблениях;

4) номинации мирян: 9 единиц в 22 употреблениях;

5) номинации, связанные с церковью как организацией: 46 единиц в 141 употреблении;

6) номинации источников вероисповедания: 29 единиц в 86 употреблениях;

7) номинации документов Церкви: 30 единиц в 148 употреблениях;

8) номинации, связанные с конфессиональным пространством: 12 единиц в 26 употреблениях;

9) номинации концептуальных понятий, связанных с вероисповеданием: 15 единиц в 58 употреблениях;

10) номинации действий и процессов, связанных с конфессиональной жизнью: 14 единиц в 65 употреблениях;

11) номинации католических богослужений: 3 единицы в 10 употреблениях.

Семантические поля классифицированы на основе следующих лексикографических источников: Leksykon chrześcijaństwa: rosyjsko-polski i polsko-rosyjski (L) познанских ученых Антони Маркунаса и Тамары Учитель (Markunas, Uczitiel 1999), а также Христианство. Русско-польский словарь (H) Романа Левицкого (Lewicki 2002), Большой толковый словарь русского языка (BTS) под редакцией Сергея Александровича Кузнецова (Kuznecov 
2004), Христианство. Словарь (М) Льва Николаевича Митрохина (Mitrohin 1994). Нами был также проведен анализ дефиниций вышеуказанных лексем в Словаре православной церковной культуры (SC) Галины Николаевны Скляревской (Sklârevskaâ 2007). В работе Скляревской была предпринята попытка дифференциации сакрально-богослужебной лексики. Ученая указывает несколько типов лексем: основные понятия вероисповедания и богословские понятия; единицы, относящиеся к лексике христианской морали; названия церковных таинств; номинации Небесной иерархии; наименования иерархов церкви; элементы церковного календаря; формы, элементы и предметы богослужения, части православного храма; имена библейских персонажей, а также названия лиц, выделяемых по каким-либо качествам, одобряемым или порицаемым православной церковью (Sklârevskaâ 7).

\section{Семантические поля конфессиональной лексики в энциклике Laudato si'}

Перейдем к характеристике семантических полей конфессиональной лексики, отобранной методом сплошной выборки из текста источника.

1. Первое поле - названия лиц. Это, во-первых названия Бога (теонимы), объекта культа и почитания. Здесь находятся единицы, называющие Божии Ипостаси и их определения; в христианстве Бог един в трех лицах: Бог Отец, Бог Сын, Бог Дух Святой.

А. Номинации Первого Божественного Лица: Бог (126), Бог Твореи (5), а также восклицания: O, Господи Боже! Господи Боже Вседержитель! Боже, Боже Всемогущий, Боже бедных, Господи Боже Триединый, Боже любви, Вседержитель! Вечный. Еще несколько имен Бога: единственный Властитель мира, Всевылний (3), Всемогущий (2), Всемогущий Бог (2), благой Владыка. Следующие номинации относятся к лексеме Отеи: Отеи (12) Отеи Твореи, Отеи Небесный, Твореи (21).

Б. Номинации Второго Божественного Лица; ядром этого поля является лексема Иисус - „Богочеловек, рожденный Девой Марией и принявший смерть на кресте во искупление человеческих грехов, затем воскресший и вознесшийся на небо; одна из ипостасей Святой Троицы” (BTS): Слово воплощенное, Сын (2), Сын Божий (2), Иисус (23), воплотившийся Сын, Сын Человеческий, Христос (2), Воскресший Христос (15), Иисус Христос (2). В эту группу стоит причислить обращение к Богу: Господи (11). 
В. Номинации Святой Троицы: Троица (6), Божественные Лища, Ипостась Троииь ('ипостась - каждое из трех лиц Святой Троицы' - Х), Единый Бог в трех ипостасях: Бога Отца, Бога Сына и Святого Духа, Бог троичен.

Г. Номинации Девы Марии и Святого Семейства: Мария (5), Мать (2), Царииа всего творения (3), Царииа небесная, Жена, Святое Семейство.

В этом семантическом поле помещаем также прилагательные:

- Божественный (20) ('1. книжн. к словам Божество и Бог; 2. относящийся к религии; церковный’ - BTS): Божественное действие, Божественный характер, Божественная благодать, Божественная благость, Божественный дар, по Божественному образиу, Божественная любовь, Божественный разум, Божественная гармония, Божественное присутствие, Божественное ,, $\mathrm{Tbl}$, ;

- Божий (62) - (“к слову Бог'), Слово Божие (Логос), Божия земля, Божий мир, Божий замысел (2), дар Божий (3), творение Божие (6), сердие Божие, мысль Божия, могущество Божие, сила Божия, сотрудник Божий, Любовь Божия (4), ласка Божия, творение Божие, действие Божие, образ Божий, орудия Божии (2).

2. Следующее поле объединяет названия библейских персонажей, святых и блаженных, обозначающих лиц, которые ближе к Богу, чем обычные верующие, оглашенные церковью. Ядрами поля мы называем два прилагательных: святой и блаженный: Святой (30), Франциисканский святой, святой покровитель (в значениях: '1. обладающий высшим совершенством и сверхъестественной силой. 2. проведший жизнь в служении Богу и церкви или пострадавший за христианскую веру и признанный церковью небесным покровителем верующих, как способный творить чудеса' - BTS), например: Святой Иоанн Павел II (5), святой Иоанн ХХІІІ, святой Франциск Ассизский (6), Франщиск (3), святой Франщиск (3), святой Бонавентура (4), святой Иоанн Креста, святой Бенедикт Нурсийский, святая Тереза из Лизьё, святой Юстин, Святой Василий Великий, Фома Аквинский (4). Слово Блаженный (2) ('христианский подвижник, призванный церковью образцом для верующих' - Н): блаженный Папа Павел VI, блаженный Шарль де Фуко.

Следующая группа относится к номинациям библейских персонажей и охватывает 4 единицы в 11 употреблениях: святой Иосиф, Каин (6), Авель (2), Ной (2). 
3. Третье поле - это названия, связанные с церковной иерархией. Наличие этой группы слов объясняется жанром энциклики, так как в заглавии читаем:

\author{
ЭНЦИКЛИКА \\ LAUDATO SI' \\ ВЕРХОВНОГО ПОНТИФИКА \\ ФРАНЦИСКА \\ ЕПИСКОПАМ, \\ ПРЕСВИТЕРАМ И ДИАКОНАМ, \\ ЛЮДЯМ, ПОСВЯЩЕННЫМ БОГУ, \\ И ВСЕМ ВЕРНЫМ МИРЯНАМ \\ О ЗАБОТЕ ОБ ОБЩЕМ ДОМЕ
}

В состав этого поля входят нижеследующие единицы: словосочетания с именами собственными Верховный Понтифик Франциск, Папа Римский (2), Папа Бенедикт (4), Бенедикт XVI (19), Иоанн Павел II (19), Папа Римский Франциск, Епископ Рима Бенедикт XVI, а также нарицательные существительные епископ (10), пресвитер (2), священник, диакон, духовенство (в значении: 'собир. священнослужители, в отличие от мирян'- Н), монах.

В состав поля входят также прилагательные с конфессиональным значением папский (8) и монашеский (2): монашеская традиция, монашеская формация ('к словам: монах и монахиня' - М).

4. Очередное поле - это названия мирян, т. е. людей, связанных с конфессиональной жизнью, последователей христианства, верующих, исповедующих христианскую религию: верный, мирянин, член Церкви, христианин (9) ('последователь христианства, верующий, исповедующий христианскую религию' - М), верующий (4) ('признающий существование Бога, верящий в Бога; религиозный, набожный' - BTS), аскет ('христианский отшельник, проводящий свою жизнь в строгом воздержании' - SC), мистик (2) ('последователь мистицизма' - L), странник (2) ('человек, странствующий пешком к святым местам, идущий на богомолье' - L), паломник ('пилигрим' - Н), богослов ('специалист по богословию; теолог' - Н).

5. Следующее поле - это лексика, связанная с церковью как организацией. Первая номинация - лексема Церковь (25) ('религиозная организация духовенства и верующих, объединенная общностью верований и обрядности; религия, проповедуемая такой организацией' - BTS), например: Католическая Церковь (10), вселенская Церковь, учение Церкви (3), Учительство Церкви. Последующие компоненты поля - это слова религия (10) ('та или иная вера; вероисповедание' - 
BTS) и христианство (2) ('одна из наиболее распространенных религий мира' - BTS). В состав этого поля входят и имена прилагательные: церковный ('относящийся к Церкви, и связанный с религией и богослужением'-BTS): церковное общение; христианский (21): христианская духовность (4), христианская мысль, христианская антропология, христианская традиция, христианские Общины, христианская религия, христианский духовнылй опыт (4) и др.; иудейско-христианский (4): иудейско-христианское мировоззрение, иудейско-христианская мысль, иудейско-христианская традиция (2); религиозный (5), например: религиозное уважение, религиозное верование, религиозный язык (2), религиозный текст; католический (17) ('к слову: католицизм, католичество и католик' - М): католический мир.

Очередная большая группа наименований в этом поле охватывает организационные формы деятельности Католической церкви, в этой группе общеязыковые значения слов пересекаются с конфессиональными. Это нижеперечисленные единицы, указанные в энциклике:

- Конференция (21) ('собрание, совещание представителей каких-либо государств, партийных, общественных, научных и т. п. организаций для обсуждения и решения каких-либо вопросов' BTS). Конференция епископов в Католической Церкви - это орган, объединяющий епископов определенной территории, чаще всего страны, направленый на координацию работы епископов и сотрудничество в решении общих проблем. Конференция епископов может назначать постоянные советы для решения конкретных проблем. В русском языке это новое конфессиональное значение, так как Конференция католических епископов России была учреждена лишь 2 марта 1999 г. Ср.: Конференция католических епископов Австралии, Конференция католических епископов Южной Африки, V Генеральная конференция епископата Латинской Америки и Карибского бассейна (2), Конференциия католических епископов Филиппин, Конференция католических епископов Японии, Конференция епископов Боливии (2), Конференция епископов Германии, Конференция католических епископов Соединенных Штатов, Конференция католических епископов Канадь, Конференциия епископов Португалии, Конференция епископов Доминиканской Республики, Конференция епископов Парагвая, Конференщия епископов Новой Зеландии, Мексиканская Епископская конференция, Национальная конференция епископов Бразилии.

- Комиссия (4) ('группа лиц или орган из группы лиц со специальными полномочиями' - ВТS): Епископская комиссия по сощиальному 
пастырству, Комиссия по сочиальным вопросам (2), Епископская комиссия по сочиальному пастырству в Аргентине.

- Cовет (7) ('представительный орган власти; одна из форм организации общества' - BTS): Папский совет „Справедливость и мир”.

- Федерация ('союз, объединение нескольких общественных организаций' - BTS): Федерачия Конференций епископов Азии.

- Собор ('собрание епископов для обсуждения важных вопросов церковной и религиозной жизни' - Л, 'собрание, съезд представителей высшего духовенства христианской церкви, общецерковный съезд' - ВTS): II Ватиканский Собор (3).

6. Далее стоит представить поле, названное нами Источники вероисповедания. В энциклике очень важны ссылки на источник веры, то есть Священное Писание, но Папа Римский также ссылается на традицию учения Церкви, то есть документы, проповеди предшественников, а также Катехизис и другие произведения Католической церкви законодательного и учительского характера. Самая большая группа включает следующие номинации: Священное Писание (3), Писание, Библия (8) ('свод священных книг иудейской и христианской религий, состоящий из Ветхого Завета, признаваемого каждым из этих вероучений, и Нового Завета, признаваемого только христианством' (Н), Слово Божие (Логос), Божественная весть. Также учитываются и названия отдельных частей: Новый Завет, Евангелие (7) ('благая весть' - L; '1. часть Библии, первые четыре книги Нового Завета, в которых излагается земная жизнь Иисуса Христа и учение о Царстве Божием' BTS): Евангелие от Иоанна, Книга Бытия (5), а также аббревиатуры - 49 единиц: Быт (14), Иер (2), Кол, Пс (6), Втор (2), Лев (5), Исх (3), Притч, Откр (2), Прем, Мф (6), Лк (3), Мк, Ин, Рим.

В этой группе также находится имя прилагательное библейский (9), например: библейские тексты, библейское законодательство, библейское повествование (5), библейская традиция, библейская вера.

7. Нижеуказанное поле составляют номинации документов Церкви и другие наименования, связанные с пастырской деятельностью Церкви. Прежде всего это названия папских документов, записанных проповедей и посланий:

- конституция (3) ('конституция церковная - документ вероучительного характера' - H): Пастырская конституция Gaudium et spes о Церкви в современном мире.

- энциклика (9) ('послание папы римского ко всем католикам по вопросам политики, религии, морали и т. п.' - BTS), например: Энциклика Redemptor hominis, Энциклика Caritas inveritate (16), 
Энциклика Laborem exercens (2), Энщиклика Centesimus annus (6), Энциклика Sollicitudo rei socialis (2), Энщиклика Populorum progressio, Энциклика Lumen fidei, Энциклика Ecclesia de Eucharistia, Энциклика Laudato si' $O$ заботе об общем доме.

- послание (24) (в значениях: '1. письменное обращение к кому-либо, письмо. [...] 4. одно из произведений раннехристианской литературы, приписываемых церковью апостолам' - BTS), например: Послание Pacem in terris, Послание ко Дню молитв о сохранении творения, Апостольское послание Octogesima adveniens, Апостольское послание Orientale lumen, Пастырское послание Responsa bilidade solidária pelo beт сотит [Солидарная ответственность за общее благо], Послание на Всемирный день мира (7), Рождественское послание, Пастырское послание What is Happening to our Beautiful Land? [Что происходит с намей прекрасной землей?], Пастырское послание об окружающей среде и человеческом развитии в Боливии El universo, don de Dios para la vida [Вселенная - дар Божий ради жизни] и др.

- декларация (8) ('название некоторых официальных документов с сообщением каких-либо нужных сведений' - BTS): Декларащия Love for Creation. An Asian Response to the Ecological Crisis [Любовь к творению. Азиатский ответ на экологический кризис] (3), Рио-де-Жанейрская декларачия по окружающей среде и развитию (4), Стокгольмская декларачия.

- обращение (13) ('призыв, речь; воззвание' - BTS): Апостольское обращение Evangelii gaudium (13).

- проповедь (5) ('поучение, речь, духовное слово, наставление священника пастве в церкви либо в ином месте' - L), например: Проповедь по случаю торжественного начала Петрова служения (2), Проповедь на мессе в торжество Тела Христова. Проповедь на Вечерне в Аосте, Проповедь на Мессе, отслуженной для сельскохозяйственных работников в Ресифе, Бразилия.

- молитва (4) (во втором значении: '2. установленный текст, произносимый верующим при обращении к Богу, к святым, а также при религиозных обрядах' - BTS).

- Катехетическая беседа (10) - искомое словосочетание отсутствует в узусе современного русского языка.

Последними в этой группе будут две единицы, обозначающие тексты вероучительного характера, катехизис (12) ('наставление, поучение' - L), например: Катехизис Католической Церкви и Компендиум сочиального учения Церкви (4). Зафиксировано также прилагательные апостольский (14) и пастырский (11). 
8. Следующее поле - номинации, связанные с конфессиональным пространством, - объединяет три группы единиц:

- Сверхъестественное пространство: Небеса (5) и небо (2) ('место, пространство, где обитают Бог, ангелы, святые и где находится рай' - BTS), небесный (6) ('исходящий, с неба как места пребывания божества' - М), например: Царство Небесное, небесный дом.

- Библейские топонимы: Иерусалим, Назарет.

- Пространство, связанное с земной Церковью: Святой Престол ('о Ватикане' - Н), епархия ('церковно-административный округ, находящийся под управлением епископа' - M), монастырь (в значениях 'уединенное место, келья отшельника' - L и 'церковь, жилые помещения и территория, принадлежащие такой общине' - BTS), храм ('здание, предназначенное для совершения богослужений и религиозных обрядов' - Н), алтарь (2) ('часть храма, в которой на возвышении находится святой престол' - М), церквушка ('здание, в котором происходит христианское богослужение' - BTS).

В это поле мы добавили предмет, создающий конфессиональное пространство - Kрест (3) как символ принадлежности к христианскому вероисповеданию.

9. Очередное поле - это нижеследующие концептуальные понятия, связанные с вероисповеданием: чудо (2) ('явление, вызванное вмешательством Божьей воли' - Л), грех (9) ('в христианском вероучении: нарушение действием, словом или мыслью воли Бога, религиозных предписаний, правил' - BTS), грехопадение ('1. нравственное падение, поступок, представляющий измену какому-либо идеалу, принципам, убеждения или нарушающий общественные нормы поведения, морали и т. п.' - BTS), вера (25), Божество (3) как черта христианского Бога (не зафиксированное значение в словарях), Воплощение (4) ('один из центральных догматов веры в христианстве, акт непостижимого соединения вечного Бога с сотворенной Богом же человеческой природой' - L), Пятидесятница ('одно из названий праздника христианской церкви, отмечаемый на пятидесятый день после Пасхи' - BTS), Аминь ('слово - аккламация, употребляется в качестве заключительного слова молитв, проповедей и т. п.; истинно, верно, да будет так' - L), Откровение (2) ('духовное видение' - BTS).

Также прилагательное богословский ('к Богословие и Богослов' - Н): богословские размышиления и теология (4) ('совокупность церковных учений о Боге и догмах религии; богословие' - BTS), богословие ('систематическое изложение и истолкование какого-либо религиозного учения, догматов какой-либо религии; теология' - BTS), 
добродетель (2) ('положительное нравственное качество человека; высокая нравственность, моральная чистота' - Н) и прилагательное сакраментальный.

10. Номинации действий и процессов, связанных с конфессиональной жизнью, выражены с помощью глаголов, отглагольных существительных и словосочетаний: крестить ('совершать обряд крещения над кем-либо' - М), поклонение (3) ('к словам: поклоняться, совершать культовые обряды перед кем-, чем-либо, почитаемым как божество, святыня, высшая сила, а также: чувство преданного восхищения, благоговения; преклонение' - М), прославить (16) ('воздать хвалу кому-либо, превознести кого-либо, восхвалить' - Н), благословить (2) (в значениях: 'перекрестить (рукой, крестом, иконой), произнося слова молитвы, напутствия, пожелания благополучия, успеха. 3. воздать хвалу, благодарность' - ВTS), молиться ('обращаться с молитвой к Богу, святым; произносить слова молитвы' - M), воздавать славу (2), воздавать хвалу (искомое слово отсутствует), молить Бога, хвалить (4) ('возносить хвалу Богу, обычно в псалмах, молитвах и т. п.' - Н), прославление (1), поклонение (3) ('к глаголу: поклоняться - т. е. совершать культовые обряды перед кем-, чем-либо, почитаемым как божество, святыня, высшая сила' - BTS), хвала (10) ('возглас или выражение восхищения, признания, благодарности' - BTS), уnование ('надежда, вера в исполнение, осуществление чего-либо' - H), ynовать ('твердо надеяться на что-либо, с надеждой, верой' - BTS), славить, катехизация (1) ('переложение христианского вероучения в виде вопросов и ответов' - ВТS), молитва (3), молитвенный (1).

11. Самое малое, однако, важное с точки зрения структуры понятийного пространства католицизма поле названий богослужений: $\mathrm{Mecca}$ (2), Вечерня (1) - и таинств: Евхаристия (7).

\section{Конфессиональная лексика как пространство традиции и современности - стилистическая и функциональная характеристика}

Детальная семантическая классификация конфессиональной лексики в рамках религиозного дискурса позволяет нам сделать еще один вывод, касающийся функционирования этих единиц в светской лексикографии, которая, как можно полагать, отражает современное состояние русского языка. Мы проанализировали дефиниции отобранной лексики в Большом толковом словаре русского языка (Kuznecov). Итак, помета 'религ.' 
содержится в словарных формулировках следующих единиц: священный, святой (2 значения), собор, откровение, пастырь, молитва, Евангелие, а помета 'церк.' - в словарных формулировках слов катехизис, ипостась, епархия ('церковно-административный округ' - BTS), монастырь, духовный, послание.

Мы проанализировали также единицы, содержащие в словарной дефиниции эксплицитную ссылку на принадлежность к христианству или слово 'христианство'. Это либо компонент дефиниции, либо примечания: 'в христианстве', 'согласно христианскому вероучению'. Итак, кроме самой группы слов Христос, христианин, христианский, христианство, выступают также следующие лексемы: блаженный, святой, иерковь, аскет, собор, библия, послание, катехизис, Вседержитель, Всевыиний, Всемогущчий, воскреснуть, Отеи, Твореи, Святой Дух, Ипостась, Бог (божий, божественньлй), Иисус, религия, крест, грех, Пятидесятница, крестить, славить.

Следующий сигнал конфессиональной принадлежности лексики - фраза 'по религиозным представлениям': покровитель, Воплощченньй, воскреснуть, Бог, небеса, небесный, душа, чудо.

Кроме того, чаще всего слова сопровождаются стилистической пометой, обозначающей высокий стиль: Вседержитель ('высок. в христианстве: одно из имен Бога'- BTS).

Можно прийти к выводу, что в толковом словаре находим общерелигиозную и общехристианскую лексику, однако 12 единиц, связанных с католическим вероисповеданием в нем не числятся. Весь корпус единиц мы проанализировали также с точки зрения наличия в словарных формулировках упоминания именно католической конфессии. Таких единиц 14. Здесь, кроме самой дефиниции прилагательного католический, следующие единицы: епископ, пресвитер, духовенство, монах, блаженный, иерковь. По отношению исключительно к католической конфессии упоминаются только 3 лексемы: nana, месса, энциклика.

В статье исследовалась конфессиональная лексика, отобранная из русского перевода энциклики Laudato si'. Лексика охарактеризована с точки зрения семантики и выполняемых функций, а также ее кодификации как в современном русском религиозном языке, так и в общелитературном языке. Адресатами энциклики являются не только представители церковной иерархии, но также все верующие, отсюда возникает необходимость обращения внимания на прагматические аспекты религиозного языка, в том числе соблюдение баланса между полным пониманием и использованием специальной конфессиональной богословской терминологии.

Говоря о прагматической значимости отобранной лексики, следует констатировать, что наиболее понятными для всех пользователей современного 
русского языка будут слова из групп, относящихся к общехристианским понятиям (всего 151 единица), а именно:

1) теонимы;

2) номинации мирян;

3) номинации источников христианского вероисповедания;

4) номинации действий и процессов, связанных с конфессиональной жизнью, которые в основном охватывают приношение хвалы единому Богу;

5) некоторые наименования, связанные с конфессиональным пространством;

6) номинации концептуальных понятий, связанных с христианским вероисповеданием.

В свою очередь, в некоторых полях находится конфессиональная католическая лексика (113 единиц). Ее нельзя назвать традиционным пластом русского языка. Самыми отдаленными в понятийном пространстве современных (в большинстве православных) пользователей русского языка будут слова и словосочетания из групп:

1) номинации святых, блаженных Католической церкви;

2) номинации священнослужителей и представителей церковной иерархии;

3) номинации, связанные с церковью как организацией;

4) номинации документов церкви (например, новые значения слов конституция, послание, энцииклика - ср. привычный для русского языка термин окружное послание);

5) номинации католических богослужений.

Таким образом, благодаря переводам католических текстов обогащается лексический фонд современного русского языка. Статус католической лексики в современном русском языке определить непросто. Конфессиональная лексика была почти полностью маргинализована в советские времена, и только в 1990-х годах Римско-католическая церковь в России начала восстанавливаться. Таким образом, анализируемая группа лексики не имеет глубоких корней в религиозном обиходе, религиозном узусе, однако является важным средством создания пространства религиозного дискурса.

Подытоживая настоящее обсуждение, мы согласимся со словами Ирены Баеровой, которая на вопрос, следует ли бояться того, что секуляризм будет проникать в религиозное пространство через ассоциации с повседневной жизнью, с современностью, отвечает, что это было бы преувеличением. Исследовательница констатирует, что не надо бояться секуляризации языка, а наоборот, необходимо поддерживать взаимосвязь языка сферы sacrum и profanum как своего рода сакрализацию мира (Bajerowa 32). Так же, как 
религия должна проникать в повседневную жизнь верующих, так и религиозный язык должен быть неотъемлемой составляющей современного общенационального языка. На основании анализа текста Энциклики о заботе об общем доме. Laudato si'мы можем утверждать, что именно таким подходом руководствуется Папа Римский Франциск.

\section{Список сокращений}

BTS - Kuznecov, Sergej A., red. Bol'šoj tolkovyj slovar' russkogo âzyka. Sankt-Peterburg, Norint, 2004.

H - Lewicki, Roman. Hristianstvo. Russko-pol'skij slovar'. Warszawa, Instytut Wydawniczy Pax, 2002.

L - Markunas, Antoni, Tamara Uczitiel. Leksykon chrześcijaństwa: rosyjsko-polski i polskorosyjski. Poznań, Wydawnictwo Naukowe UAM, 1999.

M - Mitrohin, Lev N., red. Hristianstvo. Slovar'. Moskva, Izdatel'stvo Respublika, 2004.

SC - Sklârevskaâ, Galina N. Slovar' pravoslavnoj cerkovnoj kul'tury. Moskva, AST Astrel', 2007.

\section{Источник}

Papa Rimskij Francisk. Ènciklika o zabote ob obŝem dome. Laudato sì. Moskva, Izdatel'stvo Franciskancev, 2015.

\section{Библиография}

Âkimov, Petr A. „O suŝnosti ponâtiâ «religioznaâ leksika» v sovremennoj lingvistike”. Vestnik Orenburgskogo gosudarstvennogo universiteta, 11, 2011, s. 74-76.

Âkimov, Petr A. „,Religioznaâ leksika - cerkovnaâ leksika - biblejskaâ leksika: k voprosu o sootnošenii ponâtij”. Vestnik Orenburgskogo gosudarstvennogo universiteta, 9, 2013, s. 66-69.

Ârmul'skaâ, Irina Û. „Duhovnoe poslanie kak cerkovnyj dokument”. Vestnik Volgogradskogo gosudarstvennogo universiteta, 6 (2), 2007, s. 147-150.

Bajerowa, Irena. „Kilka problemów stylistyczno-leksykalnych współczesnego polskiego języka religijnego". O języku religijnym. Zagadnienia wybrane. Red. Maria Karpluk, Jadwiga Sambor. Lublin, Redakcja Wydawnictw KUL, 1988, s. 21-44.

Ceglińska, Anetta. Piękno papieskiego stowa. O stylu encyklik Jana Pawła II. Łódź, Archidiecezjalne Wydawnictwo Łódzkie, 2000.

Gadomskij, Aleksandr K. „O žanrah religioznogo âzyka v russkoj i pol'skoj teolingvistike”. Stil, 8, 2009, s. 107-118.

Gadomskij, Aleksandr K. „Pol'skaâ i russkaâ religioznaâ leksika: popytka sistematizacii”. Krymskopol'skij sbornik naučnyh rabot. Krymsko-polskie zeszyty naukowe. T. VI. Red. Aleksandr K. Gadomskij. Simferopol', Universum, 2007, s. 287-296.

Gajda, Anetta. „Miłosierdzie większe niż sprawiedliwość. Piękno myśli i słowa w encyklice Dives in misericordia". Łódzkie Studia Teologiczne, 13, 2004, s. 273-288. 
Grzegorczykowa, Renata. Wprowadzenie do semantyki językoznawczej. Warszawa, Wydawnictwo Naukowe PWN, 2010.

Klimek, Jan. „Pedagogiczno-pastoralne aspekty encykliki Laudato si' Papieża Franciszka”. Edukacja i duchowość ekologiczna. Red. Peter Tripak, Józef Partyka. Ojców, Ojcowski Park Narodowy w Ojcowie, 2017, s. 25-39.

Kuznecov, Sergej A., red. Bol'šoj tolkovyj slovar' russkogo âzyka. Sankt-Peterburg, Norint, 2004. Lewicki, Roman. Hristianstvo. Russko-pol'skij slovar'. Warszawa, Instytut Wydawniczy Pax, 2002.

Ma, Na. „Standartizovannost' rečevogo žanra duhovnogo poslaniâ sovremennogo russkogo literaturnogo âzyka". Gumanitarnye, social'no-èkonomičeskie i obŝestvennye nauki, 9, 2015, s. 320-324. Web. 15.10.2019. https://rucont.ru/efd/376191.

Makuchowska, Marzena. „O zrozumiałości tekstów religijnych”. Pastores, 29, 2005, s. 55-64.

Markunas, Antoni, Tamara Uczitiel. Leksykon chrześcijaństwa: rosyjsko-polski i polsko-rosyjski. Poznań, Wydawnictwo Naukowe UAM, 1999.

Mitrohin, Lev N., red. Hristianstvo. Slovar'. Moskva, Izdatel'stvo Respublika, 2004.

Nagórko, Alicja. „Od antychryst do zbawić - sakralne i świeckie w leksyce”. Słowa i ich opis. Na drogach współczesnej leksykologii. Red. Dorota Zdunkiewicz-Jedynak. Warszawa, Wydział Polonistyki UW, 2012, s. 183-195.

Prohvatilova, Ol'ga A. Pravoslavnâ̂ propoved' i molitva kak fenomen sovremennoj zvučaŝej reči. Volgograd, Izdatel'stvo Volgogradskogo gosudarstvennogo universiteta, 1999.

Sklârevskaâ, Galina N. Slovar' pravoslavnoj cerkovnoj kul'tury. Moskva, AST Astrel', 2007.

Timofeev, Kirill A. Religioznâ̂ leksika russkogo âzyka kak vyraženie hristianskogo mirovozzreniâ: učebnoe posobie. Novosibirsk, Novosibirskij gosudarstvennyj universitet, 2001.

Tokarski, Ryszard. „Słownictwo jako interpretacja świata”. Współczesny język polski. Encyklopedia kultury polskiej XX wieku. T. 2. Red. Jerzy Bartmiński. Wrocław, Wiedza o Kulturze, 1993, s. 335-362.

Tokarski, Ryszard. Struktura pola znaczeniowego. Warszawa, PWN, 1984.

Wysocki, Artur. „Miejsce ubogich w koncepcji rozwoju zrównoważonego i ekologii integralnej”. Świat jako wspólny dom. Wokół koncepcji ekologii integralnej w encyklice „Laudato si”". Red. Artur Wysocki. Warszawa, Wydawnictwo Uniwersytetu Kardynała Stefana Wyszyńskiego, 2016, s. 213-258. 